\title{
Pengaruh konseling gizi dan laktasi intensif dan dukungan suami terhadap pemberian air susu ibu (asi) eksklusif sampai umur 1 bulan
}

\author{
Ramlan $^{1}$, Ani Margawati², Martha I. Kartasurya ${ }^{2}$
}

\begin{abstract}
Background : During 2012, in Muna Regency, exclusive breastfeeding practice only done by 24,6\% mothers. One of the problem is lack intensive lactation in the health service facilities. Goal of this study was to reveal the effect of intensive nutrition and lactation counseling and husband support on exclusive breastfeeding practice up to 1 month

Objective :

Methods: Quasy experiment with a control group design. The population of this study was a group of mothers who were non primaparous in the $7^{\text {th }}$ to $8^{\text {th }}$ months of pregnancy bearing the second or more. Total number of subjects were 49 mothers which were divided into 2 groups, that is the treatment group $(n=24)$ who were given intensive nutrition and lactation counseling and the control group $(n=25)$ without counseling. Univariate analysis was conducted by Shapiro Shapiro-wilk test, bivariate analysis with Mann Whitney test, Chi Square test while multivariate analysis was conducted with Logistic Regresi test.

Result: There was an increase in knowledge scores of the treatment group from 47,0\% to 77,0\%, and in the control group from 47,0\% to 53,5\%. There was an increase of attitude scores in the treatment group from 63,5\% to 77,6\%, and in the control goup from $64,8 \%$ to $68,9 \%$. The increase of knowledge $(p=0,001)$ and attitude $(p=0,006)$ scores in the treatment group was higher than the control group. The percentage of exclusive breastfeeding up to 1 month was higher in the treatment group (58,3\%) compare to the control group (20\%), with $p=0,049$ value. Husband support is confounding variabel in this study. The mothers who supported by her husband have higher opportunities 2,22 than others who unsupported by their husband with $p=0,001$ value.

Conclusion: Intensive nutrition and lactation counseling increased knowledge and attitude of exclusive breastfeeding. Husband support gave positive effect on exclucive breastfeeing till 1 month. Counseling was not effected after controlled with husband support.
\end{abstract}

Keywords: Intensive nutrition and lactation counseling, husband support, knowledge, attitude, exclusive beastfeeding.

\begin{abstract}
ABSTRAK
Latar Belakang : Cakupan ASI eksklusif di Kabupaten Muna tahun 2012 hanya mencapai 24,6\%. Salah satu penyebabnya adalah masih kurang dilakukannya konseling laktasi di sarana pelayanan kesehatan. Tujuan penelitian ini adalah utnutk menganalisis pengaruh konseling gizi dan laktasi intensif dan dukungan suami terhadap pemberian ASI eksklusif sampai umur 1 bulan.

Metode : Kuasi eksperimen dengan kelompok kontrol. Populasi dalam penelitian ini semua ibu hamil trimester 3 dengan usia kehamilan 7-8 bulan di Kabupaten Muna. Pengambilan subjek dilakukan dengan cara purposive sampling. Subjek berjumlah 49 orang yang dikelompokkan menjadi 2 kelompok yaitu kelompok perlakuan (n=24) yang mendapat konseling gizi dan laktasi intensif serta kelompok kontrol (n=25) tanpa diberi konseling. Analisis data dilakukan dengan uji mann Whitney, Chi Square dan Logistik berganda.

Hasil : Terdapat peningkatan persentase skor pengetahuan dari 47,0\% menjadi 77,0\% pada kelompok perlakuan dan 47,0\% menjadi 53,5\% pada kelompok kontrol. Terdapat peningkatan rerata skor sikap kelompok perlakuan dari 63,4\% menjadi 77,6\%, kelompok kontrol dari 64,8\% menjadi 68,9\%. Peningkatan skor pengetahuan $(p=0,001)$ dan sikap (p=0,006) kelompok perlakuan lebih tinggi dibanding kelompok kontrol. Pemberian ASI eksklusif dalam 1 bulan pertama lebih banyak dilakukan oleh ibu pada kelompok perlakuan (58,3\%) dibanding kelompok kontrol (20\%) dengan nilai p=0,015. Dukungan suami merupakan variabel perancu dalam penelitian ini. Ibu yang mendapat dukungan suami memiliki peluang memberikan ASI eksklusif 2,22 kali dibanding ibu yang tidak mendapat dukungan suami ( $p=0,001)$.

Simpulan : Konseling gizi dan laktasi yang intensif meningkatkan pengetahuan dan sikap ibu tentang pemberian ASI eksklusif. Dukungan suami berpengaruh positif terhadap pemberian ASI eksklusif selama satu bulan pertama. Konseling gizi dan laktasi intensif menjadi tidak bermakna setelah dikontrol dengan dukungan suami.
\end{abstract}

Kata kunci : konseling gizi, laktasi intensif, pengetahuan, sikap, ASI eksklusif.

\section{PENDAHULUAN}

1. Dinas Kesehatan Kabupaten Munna Sulawesi
Tenggara
2. Bagian Ilmu Gizi Fakultas Kedokteran Universitas
Diponegoro Semarang

Organisasi Kesehatan Dunia atau Word Health Organization (WHO) pada tahun 2003 dan Departemen Kesehatan Republik Indonesia melalui SK Menkes No. 450/Men.Kes/SK /IV/2004 telah menetapkan rekomendasi tentang upaya pencapaian, pertumbuhan, perkembangan, dan kesehatan yang optimal, bayi harus 
diberi ASI eksklusif selama 6 bulan pertama. Selanjutnya, demi tercukupinya nutrisi bayi, maka ibu mulai memberikan makanan pendamping ASI dan ASI hingga bayi berusia 2 tahun atau lebih, tetapi fakta di Kabupaten Muna menunjukkan bahwa praktik pemberian ASI eksklusif masih rendah. Rendahnya cakupan pemberian ASI eksklusif di Kabupaten Muna disebabkan oleh banyak faktor yang antara lain adalah pemahaman dan pengetahuan ibu tentang ASI eksklusif masih sangat kurang, pemahaman ibu yang salah tentang makanan bayi, kurangnya dukungan keluarga (ibu/mertua/suami), akibat masih kurangnya penyuluhan atau konseling laktasi yang diberikan oleh petugas kesehatan kepada ibu hamil ataupun ibu menyusui. ${ }^{1}$

United Nations International Children's Emergency Fund (UNICEF) tahun 2008 memperkirakan bahwa pemberian ASI eksklusif sampai 6 bulan dapat mencegah kematian 1,3 juta anak berusia di bawah 5 tahun. Suatu penelitian di Ghana yang diterbitkan dalam jurnal Peditrics menunjukkan bahwa 16\% kematian bayi dapat dicegah dengan pemberian ASI sejak pertama kelahirannya. Angka ini naik $22 \%$ jika pemberian ASI dimulai dalam 1 jam pertama setelah kelahiran bayi. $^{2}$

Berdasarkan profil Dinas Kesehatan Provinsi cakupan pemberian ASI eksklusif di Provinsi Sulawesi Tenggara tahun 2012 mencapai baru 25,4\%. ${ }^{3}$ sedangkan di Kabupaten Muna cakupan pemberian ASI eksklusif hanya mencapai 24,6\%. Angka tersebut masih sangat rendah apabila dibandingkan dengan target Standar Pelayanan Minimal (SPM) pemberian ASI eksklsif yakni sebesar $80 \% .^{4}$

Penelitian yang dilakukan di Bogor (2007) menemukan bahwa persentase pemberian ASI eksklusif pada ibu yang memperoleh konseling gizi tentang ASI eksklusif sebanyak 7 kali (2 kali selama hamil dan 5 kali setelah melahirkan) sebesar $20 \%$ dibanding dengan ibu yang tidak diberi konseling hanya sebesar 3.3\%. ${ }^{5}$ Penelitian lain di Brazil (2005) menunjukkan bahwa ibu yang diberi konseling sebanyak 6 kali postpartum menyusui bayi secara eksklusif sampai 4 bulan sebanyak $25 \%$ dibanding pada ibu yang tidak diberi konseling hanya $20 \%{ }^{6}$

Keberhasilan pemberian ASI eksklusif selama 6 bulan pada bayi sangat ditentukan oleh cara dan keberhasiilan pemberian ASI sejak. Bila diawali dengan cara dan strategi yang salah maka keberhasilan pemberian ASI dikemudian hari lebih sulit dicapai. Inisisasi ASI harus direncanakan dan dilakukan sejak awal dengan baik agar harapan bayi dan ibu untuk pemberian ASI ekslusif dapat lebih optimal. Ibu yang berhasil memberikan ASI eksklusif dengan baik pada satu bulan pertama akan memiliki peluang besar akan sukses memberikan ASI eksklusif pada bulan-bulan selanjutnya. ${ }^{7}$

Tujuan dari penelitian ini adalah untuk menganalisis pengaruh konseling gizi dan laktasi intensif terhadap pengetahuan, sikap dan praktik pemberian ASI eksklusif sampai imur 1 bulan.

\section{METODE}

Penelitian ini merupakan penelitian kuantitatif dengan rancangan quasi experiment with a control goup. Subjek penelitian ini adalah ibu hamil trimester 3 dengan usia kehamilan 7-8 bulan anak kedua atau lebih. Jumlah subjek penelitian ini adalah 49 ibu hamil yang dibagi dalam 2 kelompok yaitu kelompok yang mendapat konseling gizi dan laktasi intensif (perlakuan) sebanyak 24 orang dan kelompok yang hanya mendapat konseling laktasi yang selama ini dilakukan oleh bidan di puskesmas (kontrol) sebanyak 25 orang. Konseling gizi dan laktasi intensif diberikan selama 5 kali yaitu 3 kali pada saat pemeriksaan usia kehamilan 7-8 bulan dan 2 kali dilakukan melalui kunjungan rumah pada minggu ke-1 dan ke-2 setelah ibu melahirkan. Besar sampel minimal yang dibutuhkan dalam penelitian ini 46 orang. Variabel independen penelitian ini yaitu konseling gizi dan laktasi intensif, variabel dependen yakni praktik pemberian ASI eksklusif, sikap dan pengetahuan merupakan variabel antara, sedangkan pendididikan dan umur ibu, dukungan suami serta promosi susu formula merupakan variabel perancu. Data pengetahuan dan sikap, praktik ASI eksklusif, dukungan suami serta promosi susu formula diperoleh melalui pengumpulan data dengan menggunakan kuesioner yang telah diuji validitas dan realibilitasnya. Analisis data menggunakan analisis univariat, bivariat dan multivariat. Data dianalisis dengan uji Shapirowilk, uji mann Whitney, uji Chi Square dan uji Regresi Logistik.

\section{HASIL}

\section{Karakteristik Subjek Penelitian}

Tabel 1 menunjukkan bahwa tidak ada perbedaan karakteristik subjek berdasarkan umur $(\mathrm{p}=0,213)$ dan tingkat pendidikan $(\mathrm{p}=0,270)$ antara kedua kelompok perlakukan dan kontrol. Hal ini berarti bahwa penelitian ini dilakukan pada subjek dengan karakteristik yang sama 
Tabel 1. Karakteristik subjek berdasarkan umur dan pendidikan

\begin{tabular}{|c|c|c|c|c|c|c|c|}
\hline \multirow{2}{*}{$\begin{array}{l}\text { Karakteristik } \\
\text { Subjek }\end{array}$} & \multicolumn{3}{|c|}{ Perlakuan $(\mathrm{n}=24)$} & \multicolumn{3}{|c|}{ Kontrol $(n=25)$} & \multirow[b]{2}{*}{$\mathrm{p}$} \\
\hline & Min & Max & Median \pm SD & Min & Max & Median \pm SD & \\
\hline Umur (tahun) & 22 & 40 & $27,3 \pm 5,41$ & 22 & 41 & $29,2 \pm 5,90$ & $0,213^{\mathrm{a}}$ \\
\hline $\begin{array}{l}\text { Pendidikan } \\
\text { (tahun) }\end{array}$ & 6 & 16 & $11,5 \pm 2,39$ & 6 & 16 & $10,7 \pm 2,47$ & $0,270^{\mathrm{a}}$ \\
\hline
\end{tabular}

\section{Pengetahuan Ibu Setelah Konseling Gizi dan Laktasi dan Intensif}

Pengetahuan sebelum dan sesudah perlakuan antara kelmpok perlakuan dan kontrol

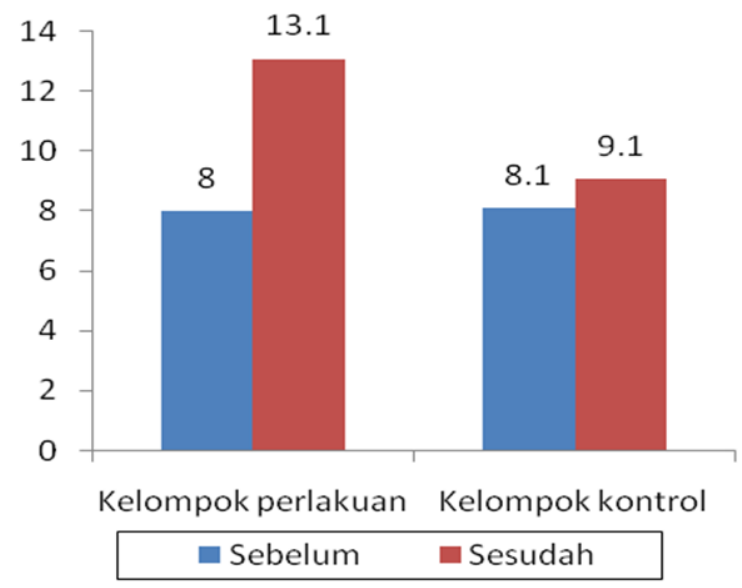

Ganbar 1. Rerata skor pengetahuan sebelum dan sesudah perlakuan antara kelompok perlakuan dan kontrol

Gambar 1 menunjukkan bahwa peningkatan skor pengetahuan lebih tinggi pada kelompok perlakuan dibanding kelompok kontrol. Artinya peningkatan pengetahuan ibu yang mendapat konseling gizi dan laktasi yang intensif lebih tinggi dibanding ibu yang tidak mendapatkan konseling yang intensif. Hal ini menunjukkan bahwa ada pengaruh konseling gizi dan laktasi yang intensif terhadap pengetahuan ibu.

\section{Sikap Ibu Setelah Konseling Gizi dan Laktasi Intensif}

Gambar 2 menunjukkan bahwa perbedaan rerata skor sikap antara kelompok perlakuan dan kontrol sebelum perlakuan sama, tetapi menjadi berbeda setelah perlakuan. peningkatan skor sikap lebih tinggi pada kelompok perlakuan dibanding kelompok control. Artinya peningkatan pengetahuan ibu yang mendapat konseling gizi dan laktasi yang intensif lebih tinggi dibanding ibu yang tidak mendapatkan konseling yang intensif. Hal ini menunjukkan bahwa ada pengaruh konseling gizi dan laktasi yang intensif terhadap sikap ibu.
Sikap sebelum dan sesudah perlakuan antara kelmpok perlakuan dan kontrol

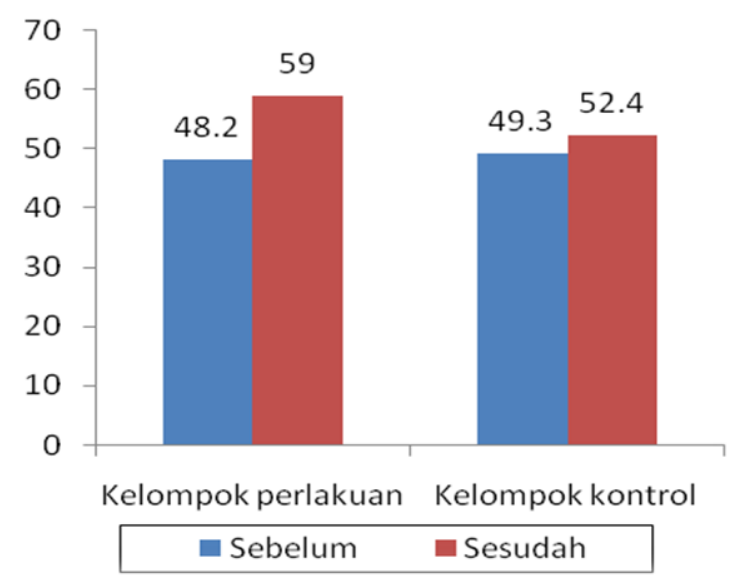

Gambar 2. Grafik rerata skor sikap sebelum dan sesudah perlakuan antara kelompok perlakuan dan kontrol

\section{Praktik Pemberian ASI Eksklusif Sebelum dan Sesudah Konseling Gizi dan Laktasi Intensif}

Praktik pemberian ASI Eksklusif sebelum dan sesudah perlakuan antara kelmpok perlakuan dan kontrol

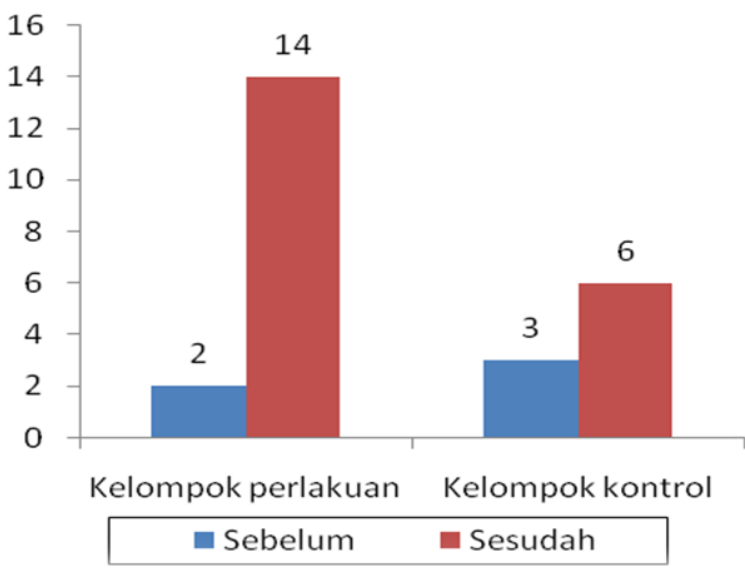

Gambar 3. Grafik pemberian ASI eksklusif sebelum dan sesudah perlakuan antara kelompok perlakuan dan control

Perbedaan praktik pemberian ASI merupakan perbandingan jumlah subjek yang memberikan ASI 
eksklusif ada atau tidak ada pengaruh perlakuan antara kelompok perlakuan dibanding kelompok kontrol baik sebelum maupun sesudah perlakuan. Praktik pemberian ASI Eksklusif sampai 1 bulan yang dilakukan pada anak sebelum dan selama penelitian antara kelompok perlakuan dan kontrol.

\section{Dukungan Suami dan Promosi Susu Formula Terhadap Pemberian ASI Eksklusif}

Dukungan suami dan promosi susu formula merupakan variabel parancu yang dapat mempengaruhi praktik pemberian ASI eksklusif dalam penelitian ini.
Untuk memastikan ada atau tidak ada pengaruh dari kedua variable perancu tersebut terhadap praktik pemberian ASI ekskluisf maka perlu dilakukan analisis. Tabel 2 dan table 3 masing-masing menunjukkan persentase dukungan suami dan paparan promosi susu formula terhadap pemberian ASI eksklusif antara kelompok perlakuan dan kontrol.

Tabel 2 menunjukkan bahwa sebagian besar $(58,3 \%)$ suami pada kelompok perlakuan mendukung pemberian ASI eksklusif sementara pada kelompok kontrol sebagian besar $(72,0 \%)$ kurang mendukung.

Tabel 2. Dukungan suami terhadap pemberian ASI eksklusif antara kelompok perlakukan dan kelompok kontrol

\begin{tabular}{lcccc}
\hline & \multicolumn{2}{c}{$\begin{array}{c}\text { Perlakuan } \\
(\mathrm{n}=24)\end{array}$} & \multicolumn{2}{c}{$\begin{array}{c}\text { Kontrol } \\
(\mathrm{n}=24)\end{array}$} \\
\cline { 2 - 5 } & $\mathrm{N}$ & $\%$ & $\mathrm{~N}$ & $\%$ \\
\hline Mendukung & 14 & 58,3 & 7 & 28,0 \\
\hline Kurang Mendukung & 10 & 41,7 & 18 & 72,0 \\
\hline
\end{tabular}

Tabel 3. Paparan promosi susu formula terhadap pemberian ASI eksklusi antara kelompok perlakukan dan kelompok kontrol

\begin{tabular}{lcccc}
\hline & \multicolumn{2}{c}{$\begin{array}{c}\text { Perlakuan } \\
(\mathrm{n}=24)\end{array}$} & \multicolumn{2}{c}{$\begin{array}{c}\text { Kontrol } \\
(\mathrm{n}=24)\end{array}$} \\
\cline { 2 - 5 } & $\mathrm{N}$ & $\%$ & $\mathrm{~N}$ & $\%$ \\
\hline Terpapar & 19 & 79,1 & 21 & 84,0 \\
\hline Tidak Terpapar & 5 & 20,9 & 4 & 16,0 \\
\hline
\end{tabular}

Tabel 3 menunjukkan bahwa sebagian besar subjek pada kedua kelompok terpapar oleh promosi susu formula.
Langkah selanjutnya adalah melakukan analisis terhadap data dukungan suami dan paparan promosi susu formula terhadap pemberian ASI eksklusif.

Tabel 4. Dukungan suami dan promosi susu formula terhadap pemberian ASI eksklusif

\begin{tabular}{lllcl}
\hline & \multicolumn{1}{c}{ Variabel } & Koefisien & $\mathrm{p}$ & \multicolumn{1}{c}{ OR(IK95\%) } \\
\hline Langkah 1 & Status konseling & 0,861 & 0,395 & $2,36(0,32-17,20$ \\
& Dukungan suami & 1,100 & 0,005 & $3,00(1,39-6,45)$ \\
& Promosi susu formula & $-0,496$ & 0,274 & $0,60(0,25-1,48)$ \\
& & & & \\
Langkah 2 & Status konseling & 0,717 & 0,469 & $2,04(0,29-14,31)$ \\
& Dukungan suami & 0,800 & 0,001 & $2,22(1,44-3,43)$ \\
\hline
\end{tabular}

Regresi Logistik

Hasil uji regresi logistik menunjukkan adanya perbedaan dukungan keluarga antara kelompok perlakuan dengan kelompok kontrol $(\mathrm{p}=0,002)$. Terhadap paparan promosi susu formula dari hasil uji statistik tidak menunjukkan adanya perbedaan bermakna antara kelompok perlakuan dengan kelompok kontrol $(\mathrm{p}=0,119)$.

\section{PEMBAHASAN}

Subjek pada awal penelitian sebanyak $50 \mathrm{ibu}$ hamil dari 2 puskesmas (Puskesmas Parigi dan Puskesmas Kabawo) yang dibagi dalam 2 kelompok yaitu kelompok perlakuan sebanyak 24 orang dan kelompok kontrol sebanyak 26. Diakhir penelitian, subjek pada kelompok perlakukan tetap 24 orang sedangkan pada kelompok kontrol ada 1 subjek yang pindah keluar daerah, dengan demikian diakhir penelitian jumlah subjek pada kelompok kontrol tersisa 
25 orang. Hasil analisis (Tabel 1) menunjukkan bahwa tidak ada perbedaan karakteristik subjek berdasarkan umur $(\mathrm{p}=0,213)$ dan tingkat pendidikan $(\mathrm{p}=0,270)$ antara kedua kelompok perlakukan dan kontrol. Hal ini berarti bahwa penelitian ini dilakukan pada subjek dengan karakteristik yang sama antara kelompok kontrol dan kelompok.

Hasil uji Mann Whitney menunjukkan bahwa tidak ada perbedaan rerata skor pengetahuan antara kelompok perlakuan dan kontrol sebelum perlakuan $(\mathrm{p}=0,177)$, tetapi terdapat perbedaan setelah perlakuan $(\mathrm{p}=0,017)$. Hasil uji Mann Whitney juga menunjukkan bahwa terdapat perbedaan perubahan skor pengetahuan antara kelompok perlakuan dengan kelompok kontrol $(\mathrm{p}=0,001)$.

Sebelum perlakuan subjek pada kelompok perlakuan dan kontrol memiliki pengetahuan yang sama. Hal ini disebabkan karena ibu kurang mendapat informasi dan hanya belajar dari pengalaman pada anak sebelumnya. Hasil penelitian yang dilakukan di Medan tahun 2005 menemukan bahwa setiap ibu yang memeriksakan kehamilannya, informasi yang didapatkan lebih banyak berkaitan dengan kondisi kehamilan dan persiapan melahirkan, sedangkan informasi tentang persiapan agar sukses menyusui bayinya jarang diterima. ${ }^{8}$

Pada akhir penelitian kelompok yang mendapat konseling gizi dan laktasi yang intensif menunjukkan peningkatan pengetahuan yang lebih tinggi dibanding kelompok kontrol. Hal ini sejalan dengan penelitian di Makassar yang menemukan adanya peningkatan pengetahuan subjek setelah dilakukan edukasi IMD. ${ }^{9}$ Penelitian lain juga menyatakan hal yang sama yaitu terjadi peningkatan pengetahuan tentang ASI eksklusif kepada bayinya setelah dilakukan konseling gizi. Ada perbedaan pengetahuan pada kedua kelompok setelah dilakukan konseling gizi, dimana ibu yang mendapatkan konseling gizi akan mempunyai tingkat pengetahuan yang lebih baik dari kelompok yang tidak mendapat konseling. ${ }^{5}$

Keterbukaan dalam komunikasi antara konselor dan ibu serta kemampuan konselor yang menunjukkan sikap bersedia menjadi pendengar yang baik serta menciptakan suasana yang nyaman akan dapat menggali sejauhmana pengetahuan ibu dan mengembangkan pengetahuan ibu tersebut menjadi lebih baik. Faktor lain yang menjadi penyebab keberhasilan dalam proses konseling adalah konselor mampu menumbuhkan kepercayaan dan motivasi ibu, sehingga ibu bisa menerima konselor sebagai sumber informasi yang berdampak terhadap keberanian ibu untuk mengungkapkan ketidaktahuan yang dihadapi sebelumnya. Untuk mempermudah pemahaman ibu tentang materi pembelajaran yang diberikan oleh konselor maka materi yang disampaikan berasal dari masalah-masalah yang ingin diketahui ibu tersebut. Masalah yang disampaikan berdasarkan pengalaman ibu pada anak sebelumnya, kemudian informasi tersebut selanjutnya oleh konselor dipadukan dengan pendapat para ahli dan beberapa hasil penelitian yang dirangkum dan disampaikan dengan bahasa yang mudah dipahami. ${ }^{10}$

Intensitas konseling juga merupakan salah satu yang mempengaruh peningkatan pengetahuan ibu, semakin sering terjadi kontak antara ibu dan konselor maka semakin sering ibu mendapatkan informasi yang secara tidak langsung meningkatkan pengetahuannya. Manfaat lain dari intensitas konseling yang sering adalah adanya pengulangan informasi yang menjadi faktor pendukung dalam pemahaman ibu terhadap informasi tersebut. Informasi atau pengetahuan yang sering dan berulang-ulang dapat meningkatkan retensi pengetahuan seseorang. Waktu yang digunakan untuk konseling disesuaikan dengan waktu yang diinginkan oleh ibu, hal ini akan berdampak terhadap kesiapan ibu dalam mengikuti konseling sehingga membuat suasana proses belajar lebih kondusif dan berdampak terhadap keberhasilan dalam penerimaan informasi tersebut. Media komunikasi yang digunakan konselor mampu memberikan informasi yang mudah diterima dan mudah diingat oleh ibu sehingga mendorong keinginan ibu untuk mengetahui dan akhirnya mendapatkan pemahaman yang lebih baik. ${ }^{11}$

Konseling gizi dan laktasi yang intensif yang diberikan selama perlakuan, didukung dengan kemampuan konselor dalam memadukan antara pendapat para ahli dan pengalaman ibu menyusui pada anak sebelumnya menyebabkan adanya peningkatan pengetahuan ibu menjaadi lebih baik. Kondisi tersebut memberi dampak langsung terhadap kesadaran dan motivasi ibu untuk melakukan IMD, memberi kolostrum, menyusui dengan kedua payudara serta menyusui bayinya secara eksklusif selama 1 bulan pertama. Hal ini sesuai dengan penelitian yang dilakukan di Makassar tahun 2011 yang menemukan bahwa faktor yang mendukung pemberian ASI Eksklusif adalah pengetahuan ibu dan bantuan petugas kesehatan yang profesional. ${ }^{12}$

Konseling gizi dan laktasi yang intensif yang diberikan selama perlakuan juga perpengaruh terhadap perubahan sikap. Hasil uji Mann Whitney menunjukkan bahwa tidak ada perbedaan rerata skor sikap antara kelompok perlakuan dan kontrol sebelum perlakuan $(p=0,520)$, tetapi terdapat perbedaan setelah perlakuan $(\mathrm{p}=0,006)$. Hasil uji Mann Whitney juga menunjukkan bahwa terdapat perbedaan perubahan skor sikap antara kelompok perlakuan dengan kelompok kontrol $(\mathrm{p}=0,001)$ yang berarti bahwa ada pengaruh konseling gizi dan laktasi yang intensif terhadap sikap ibu. Hal ini disebabkan pada kedua kelompok tersebut memiliki pengetahuan yang kurang. 
Terhadap pernyataan tentang sikap ibu dari kedua kelompok menunjukkan bahwa sebagian besar masih menunjukkan sikap yang negatif, hal ini menggambarkan bahwa pada awal penelitian ibu menunjukkan respon yang kurang baik terhadap pertanyaan tersebut.

Konseling gizi dan laktasi yang intensif yang diberikan selama perlakuan, didukung dengan kemampuan konselor dalam memadukan antara pendapat para ahli dan pengalaman ibu menyusui pada anak sebelumnya menyebabkan adanya peningkatan pengetahuan ibu menjaadi lebih baik. Kondisi tersebut memberi dampak langsung terhadap kesadaran dan motivasi ibu untuk melakukan IMD, memberi kolostrum, menyusui dengan kedua payudara serta menyusui bayinya secara eksklusif selama 1 bulan pertama. Hal ini sesuai dengan penelitian yang dilakukan di Makassar tahun 2011 yang menemukan bahwa faktor yang mendukung pemberian ASI Eksklusif adalah pengetahuan ibu dan bantuan petugas kesehatan yang profesional. ${ }^{12}$

Faktor lain yang membentuk sikap ibu adalah pengetahuan dan evaluasi dari pengalaman pada anak sebelumnya dan praktik pemberian ASI eksklusif yang ada di masyarakat yang sebagian besar tidak eksklusif, kondisi tersebut akan mempengaruhi motivasi dan emosi ibu yang pada akhirnya akan memberikan penilaian yang relatif tetap baik sebelum maupun sesudah perlakuan. Sikap timbul karena adanya stimulasi serta dapat berkembang manakala mendapat pengaruh, baik dari dalam maupun luar yang bersifat positif atau mengesankan. ${ }^{13}$ Faktor lain yang membentuk sikap ibu adalah pengalaman menyusui pada anak sebelumnya yang sebagian besar tidak eksklusif. Kondisi ini akan mempengaruhi motivasi dan emosi ibu yang pada akhirnya akan memberikan penilaian yang relatif tetap baik sebelm maupun sesudah perlakuan. ${ }^{12}$ Selain yang telah disebutkan di atas, sikap juga dipengaruhi oleh pengetahuan. Hasil penelitian menunjukkan bahwa pengetahuan berhubungan dengan sikap, pengetahuan ASI akan mempengaruhi sikap terhadap pemberian ASI. ${ }^{14}$

Hasil uji statistik menunjukkan bahwa tidak ada perbedaan praktik pemberian ASI eksklusif antara ibu pada kelompok perlakuan dengan kelompok kontrol $(\mathrm{p}=0,675)$ sebelum perlakuan, tetapi ada perbedaan yang bermakna setelah perlakuan $(\mathrm{p}=0,016)$. Hasil analisis tersebut menunjukkan bahwa pemberian ASI eksklusif lebih tinggi pada kelompok perlakuan dibanding kelompok kontrol setelah perlakuan. Hasil uji statistik menunjukkan ada perbedaan praktik pemberian ASI eksklusif antara kelompok perlakuan dengan kontrol $(\mathrm{p}=0,001)$, perbedaan ini disebabkan karena adanya perbedaan peningkatan pengetahuan dan perubahan sikap pada ibu antara kelompok perlakuan dengan kelompok kontrol. Sebuah penelitian yang dilakukan di Makassar tahun 2011 membuktikan bahwa konseling prenatal memiliki dampak terhadap pemberian ASI sampai 4-6 minggu, sedangkan konseling yang diberikan pada saat pranatal dan postnatal berpengaruh terhadap pemberian ASI eksklusif sampai dengan 6 bulan. Setelah melahirkan merupakan masa kritis dalam pemberian ASI karena masalah menyusui itu muncul, dengan adanya konseling laktasi yang intensif membantu ibu untuk meningkatkan kemampuan dan keterampilan dalam menghadapi kesulitan dalam pemberian ASI. Konseling dapat membantu ibu untuk memperoleh bukan saja kemampuan, minat dan kesempatan melainkan juga emosi dan sikap yang bisa mempengaruhi dalam menentukan pilihan dan pengambilan keputusan. Adanya perhatian dan pemberian motivasi dalam bentuk kunjungan rumah setelah melahirkan oleh konselor terhadap ibu menjadi dukungan dalam pemberian ASI eksklusif. ${ }^{15}$

Pada akhir penelitian ini menunjukkan bahwa konseling laktasi yang intensif meningkatkan jumlah ibu yang memberikan ASI eksklusif. Hasil penelitian ini sesuai dengan penelitian yang dilakukan di Ghana yang menyatakan bahwa praktik pemberian ASI eksklusif lebih tinggi pada ibu yang mendapatkan konseling laktasi (39,5\%) dibanding dengan ibu dengan ibu yang tidak mendapatkan konseling. ${ }^{9}$ Penelitian lain menemukan bahwa terjadi peningkatan jumlah ibu yang memberikan ASI eksklusif setalh dilakukan konseling laktasi yang intensif. ${ }^{16}$

Hasil uji regresi logistik menunjukkan bahwa dari dua variabel perancu yang dianalisis dukungan suami merupakan variabel yang berpengaruh terhadap praktik pemberian ASI eksklusif $(\mathrm{p}=0,001)$ sebagaimana ditunjukkan pada Tabel 4. Dari hasil analisis tersebut dapat disimpulkan bahwa ibu yang mendapat dukungan suami memiliki peluang 2,22 kali memberi ASI eksklusif disbanding ibu yang tidak memndapat dukungan suami.Pengaruh konseling gizi menjadi tidak bermakan setelah dikontrol dengan dukungan suami. Hal ini menunjukkan bahwa untuk meningkatkan pengetahuan dan sikap ibu tentang ASI eksklusif cukup dengan hanya dilakukan konseling pada ibu tanpa melibatkan suami, tetapi untuk mewujudkan prilaku pemberian ASI ekskluais maka perlu keterlibatan suami dalam konseling tersebut.

Penelitian lain yang yang dilakukan di Semarang tahun 2009 sejalan dengan penelitian ini yang menunjukkan bahwa salah satu orang yang mempengaruhi praktik pemberian ASI eksklusif adalah suami. ${ }^{17}$ Penelitian lain yang dilakukan di Semarang tahun 2013 juga menemukan bahwa keberhasilan pemberian ASI eksklusif selama 6 bulan pertama karena merupakan keputusan sang ibu dan didukung oleh suaminya. ${ }^{18}$ 


\section{SIMPULAN}

Penelitian ini menyimpulkan bahwa konseling gizi dan laktasi intensif yaitu sebanyak 3 kali pada saat pemeriksaan kehamilan usia kehamilan 7-8 bulan dan 2 kali setelah melahirkan melalui kunjungan rumah berpengaruh terhadap peningkatan pengetahuan, sikap ibu tentang ASI eksklusif. Dukungan suami berpengaruh positif terhadap pemberian ASI eksklusif. Pengaruh konseling menjadi tidak bermakna setelah dikontrol dengan dukungan suami.

\section{SARAN}

Saran yang dapat diberikan antara lain sebaiknya melibatkan suami dalam kegiatan konseling ataupun penyuluhan yang berkaitan dengan pemberian ASI eksklusif baik yang dilakukan oleh lembaga pelayanan kesehatan atau lembaga terkait lainnya demi terwujudnya upaya peningkatan pemberian ASI eksklusif.

\section{DAFTAR PUSTAKA}

1. Prasetyono D.S. ASI Eksklusif Pengenalan, Praktik dan kemanfaatannya. Yogyakarta: Diva Press; 2009. Hal 86-102

2. Dinas Kesehatan Provinsi Sulawesi Tenggara. Profil Kesehatan Provinsi Sulawei Tenggara. 2012. Hal 216

3. Dinas Kesehatan Kabupaten Muna. Profil Kesehatan Kabupaten Muna, Dinkes Kab. Muna; 2012. Hal 198-209

4. Widyastuti E. Hubungan Riwayat Pemberian ASI eksklusif dengan Status Gizi Bayi di Propinsi Nusa Tenggara Barat. Tesis Program Pascasarjana Universitas Gajah Mada Yogyakarta. Yogyakarta. 2009. Hal 98-122

5. Nurhayati A. Pengaruh Konseling Gizi pada ibu keluarga miskin terhadap Pemberian ASI Eksklusif. Tesis program Studi Gizi Masyarakat dan Sumberdaya Keluarga. Bogor. Institut Pertanian Bogor; 2007. Hal 82-118

6. Liete et. al. Effectiveness of Home-Based Peer Cuoncelling to promote Breast feeding in the Northearst of Brazil Effectiveness of Home-Based Peer Cuoncelling to promote Breast feeding in the Northearst of Brazil. Acta Pediatrica; 2005 p. 1-7

7. Gupta A. Inititation brestfeeding by breart crawl. India. UNICEF Maharastgra; 2007.p.21-31

8. Susilowaty et al. Determinan social budaya pada pemberian ASI eksklusif di wilayah kerja Puskesmas Padang Bulan dan PB. Selayang II Kota Medan. 2005. Hal 52-73
9. Aidam BA et. Al. Lactation Councelling Increases Exclusive Breast-Feeding Rates in Ghana. The Journal of Nutrition. 2005. 135:1691-1695

10. Azwar A. Pelaksanaan Pemberian ASI Eksklusif di Indonesia. Makalah disampaikan pada Pertemuan Pakar (Expert Consultation) Masalah Pemberian ASI kaitannya dengan Tumbuh Kembang Anak di Indonesia. Jakarta. 2003.Hal 64-85

11. Notoatmodjo S. Pendidikan dan Perilaku Kesehatan. Jakarta. Rineke Cipta; 2003. Hal 102136

12. Bohari, Asriani A. Perubahan Pengetahuan, Sikap ibu Hamil Setelah Edukasi dan Praktek Inisiasi Menyusu Dini di RSIA Siti Fatimah Kota Makassar. Makassar. Program Pascasarjana Universitas Hasanuddin; 2011. Hal 89-91

13. Azwar S. Sikap manusia Teori dan Pengukuran. Yogyakarta. Pustaka Pelajar; 2007. Hal 102-143

14. Briawan D, Suciarni E. Hubungan Pengetahuan, Sikap dan Praktek ibu dengan Berkelanjutan Pemberian ASI Eksklusif dari Umur 4-6 bulan, Media Gizi dan Keluarga; Juli 2007. 31 (1) : 5462

15. Gunarsa SD. Konseling dan Terapi. Jakarta. PT BPK Gunung Mulia; 2009. Hal. 89-94

16. Ambarwati R. Pengaruh Konseling Laktasi Intensif Terhadap Pemberian ASI Eksklusif sampai umur 3 bulan. Tesis Program Studi Ilmu Gizi Fakultas kedokteran Universitas Diponegoro. Semarang. 2012. Hal.49-71

17. Noer ER. Beberapa Faktor Determinan Praktik Inisiasi Menyusu Dini dan Pemberian ASI eksklusif selama 4 Bulan. Tesis Program Pascasarjana Universitas Diponegoro. Semarang. 2009. Hal 87

18. Putri, R.M.E. Peran Ayah/suami dalam pemberian ASI Eksklusif. Tesis Program Studi Ilmu Gizi Fakultas Kedokteran Universutas Diponegoro. Semarang. 2013. Hal.109 